\title{
The Role of Sex-specific Long Non-coding RNAs in Cancer Prevention and Therapy
}

\author{
Hye Kyung Song, Sun Young Kim \\ Department of Chemistry, College of Science and Technology, Duksung Women's University, Seoul, Korea
}

\begin{abstract}
The functions of a large number of non-coding genes in human DNA have yet to be accurately identified. Long non-coding RNA (IncRNA) measuring $10 \mathrm{~kb}$ or less in length regulates transcription or post-transcriptional events. The IncRNAs have attracted increased attention of researchers in recent years. In this review, we summarize the recently published IncRNAs which are known to influence cancer development and progression. We also discuss recent studies investigating tumor-specific IncRNA expression. These IncRNAs provide very useful information that allows prediction of the degree of malignancy and a survival rate in cancer patients as clinically relevant biomarkers. Because symptoms and progression of cancer differ from onset to death between males and females, it is important to consider the gender of the patient when diagnosing cancer and predicting the progression. Considering the importance of gender difference, we also examine the influence of sex hormones involved in the expression and regulation of IncRNAs as biomarkers. Many of the IncRNAs examined in this review have been studied in cancers occurring in the female or male reproductive organs, but the association between IncRNAs and sex hormones has also been reported in common organs such as the lung, renal and colon. Although IncRNAs have not yet been widely used as definitive cancer indicators, recent studies have demonstrated the potential role of IncRNAs as biomarkers and therapeutic targets reflecting sex-specificity in a number of different cancers.
\end{abstract}

Key Words LncRNA, Sex-specificity, Cancer, Biomarker, Sex hormone

\section{INTRODUCTION}

All living organisms store their biometric information in the genome and express specific genes as needed in order to ensure the efficiency of biological processes and generate genetically stable descendants. Defective biological events can lead to disease and disability. Therefore, the body is equipped with a variety of systems to regulate the expression of genetic information via a plethora of regulatory proteins and genomic transcripts. Non-coding genes account for $98 \%$ of human genes, and the non-coding RNAs (ncRNAs) also play an important role [1,2].

The long non-coding RNAs (IncRNAs) described in this study include ncRNAs measuring 200 nucleotides (nt) to $10 \mathrm{~kb}$ in length, and account for $80 \%$ of total ncRNAs [3,4]. Among the ncRNAs that act as direct regulators of transcription and post-transcriptional events, IncRNAs have attracted increased attention in recent years when compared with small ncRNAs (20- to 200-nt), which were previously the pri- mary study targets due to their small size $[5,6]$. A number of reports suggest that IncRNAs regulate the expression of adjacent genes. Defective IncRNAs induce the development of cancer, abnormal immune response, and metabolic disease [7]. In particular, IncRNAs are involved in cancer cell growth, death, migration, and metastasis by regulating the expression of oncogenes or tumor suppressor genes, resulting in chromosomal remodeling and induction of morphological changes $[8,9]$.

Cancer is one of the leading causes of death worldwide, although its incidence varies internationally. In addition to genetic factors, altered regulatory processes trigger the onset of cancer following exposure to lifestyle patterns, smoking or drinking alcohol, and environmental pollutants [10,11]. Malignant cancer is attributed to failed regulatory mechanisms and often leads to death [12]. Sex-based differences in the incidence and malignancy of cancer are also important as some cancers are triggered by errors in sex chromosomes or under the influence of sex hormones [13,14].

Received March 15, 2021, Revised May 11, 2021, Accepted May 21, 2021

Correspondence to Sun Young Kim, E-mail: neomiriam@duksung.ac.kr, https://orcid.org/0000-0002-5994-8889

Check for updates

(i) (\$) This is an Open Access article distributed under the terms of the Creative Commons Attribution Non-Commercial License, which permits unrestricted noncommercial use, distribution, and reproduction in any medium, provided the original work is properly cited.

Copyright $\odot 2021$ Korean Society of Cancer Prevention 
In this review, we introduce IncRNAs thought to be related to cancer and summarize those that are known to facilitate the diagnosis and treatment of malignancies. Our analyses suggest that some of these IncRNAs represent valuable biomarkers compared with more conservative biomarkers, such as carcinoembryonic antigen, and cancer antigens (CAs) 19-9 and $129[5,15,16]$. In addition, we summarize IncRNAs exhibiting sex-specific regulatory potential in various cancers. As a whole, this review seeks to evaluate the potential role of sex-specific IncRNAs as therapeutic targets or diagnostic indicators in cancer.

\section{REVIEWS OF RECENT STUDIES FOR LONG NON-CODING RNAS}

\section{Cancer-related IncRNAs}

It is well-known that IncRNAs play an important role in gene expression by regulating the composition of nuclear structure and gene transcription as well as the stability, translation, and post-translational modification of mRNA in the cytoplasm [17]. In this section, we investigate recent studies investigating the effects of IncRNAs on cancer and the development, proliferation, migration, and invasion of cancer cells $[18,19]$.

\section{Tumorigenesis}

Several IncRNAs are known to promote cancer development and progression by inducing immune escape mechanisms, which alter the functional state of immune cells. Immune escape refers to the escape of tumor cells from killer $T$ cells by regulating the function of macrophages and regulatory $T$ cells (Tregs) $[20,21]$. The IncRNA Inc-EGFR has been shown to promote the development and progression of hepatocellular carcinoma by inducing immune escape via Treg cell differentiation [22]. Similarly, IncRNA LNMAT1 was shown to mediate the regulation of $\mathrm{C}-\mathrm{C}$ Motif Chemokine Ligand 2, which attracts macrophages in the tumor microenvironment and restricts phagocytosis, thereby promoting cancer progression [23].

In addition, IncRNAs may induce and promote cancer by disrupting mitochondrial function and cell metabolism. The IncRNA SAMMSON plays a role in promoting cancer by binding to the p32 protein, an important mitochondrial regulator in melanoma cells [24]. Additionally, the IncRNA LINK-A, along with hypoxia-inducible factor 1-alpha, acts as an important activator of energy metabolism in cancer cells and induces the progression of oral cancer [25]. Finally, IncRNA HOXBAS3 has been shown to affect the expression of the conserved 53-amino acid peptide, thus affecting metabolic action and therefore cancer cell progression [26].

\section{Proliferation}

The IncRNA LUNAR1 is induced by the oncogene Notch1 in T-cell acute lymphoblastic leukemia and promotes the partial growth of cancer cells [27]. The IncRNA FAL1 is located with- in the region of chromosome 1 that is amplified in cancer and promotes the proliferation of tumor cells by mobilizing several genes, including CDKN1A [28].

In addition, many IncRNAs are targets for the transcriptional regulation of $\mathrm{Myc}$, resulting in the promotion and proliferation of cancer cells [29]. The IncRNA PVT1 induces the proliferation of cancer cells via Myc in murine models of tumorigenesis [30]. Additionally, the IncRNA CCAT1induced the proliferation of colon cancer via interaction between Myc transcription and Myc-related enhancers [31,32]. Finally, IncRNA PCGEM1 specifically binds to Myc in the prostate and activates the transcription of Myc in prostate cancer (PC) cells [33].

\section{Metastasis}

The epithelial-mesenchymal transition (EMT) process refers to a phenomenon in which epithelial cells can be converted into mesenchymal cells $[34,35]$. EMT can be regulated by various EMT-inducing transcription factors and is known to facilitate cancer cell invasion and migration into the surrounding blood and lymphatic vessels $[35,36]$. Several studies have reported that IncRNAs are also associated with EMT regulation in tumors $[37,38]$. IncRNA-ATB induced liver cancer metastasis by upregulating the levels of zinc finger E-box-binding homeoboxes (ZEB) 1 and 2, which are involved in the induction of EMT [19]. In addition, IncRNA LIN28B was induced by TGF- $\beta$, which has been shown to promote the development and proliferation of pancreatic ductal adenocarcinoma [39]. The level of IncRNA-hDREH was decreased by hepatitis B virus $X$ protein, which inhibits EMT in hepatocellular carcinoma (HCC) [40]. It is also well-known that the IncRNA PNUTS can promote breast cancer metastasis by inducing EMT [41]. Additionally, the IncRNA HOTAIR (HOX transcript antisense RNA) is induced by TGF- $\beta$ and activates the SMAD signaling cascade, which induces the EMT in cancers of pancreas, liver, and breast $[37,42-44]$. Reports also showed that the overexpression of IncRNA MALAT1 (metastasis-associated lung adenocarcinoma transcript 1) increased cancer cell metastasis in patients with non-small cell lung cancer (NSCLC) [45]. In vivo studies using murine models showed that the inhibition of MALAT1 down-regulated lung cancer cell motility and reduced metastatic potential [46]. The IncRNA SChLAP1 promotes metastasis and invasion by PC cells inhibiting the metastatic function of the SWItch/Sucrose Non-Fermentable (SWI/SNF) complex $[47,48]$.

Stemness is an important feature for the initiation of metastasis. Cells with strong stemness can lead to macrometastasis [49]. Several studies have reported that IncRNAs regulate and promote the stemness of cells. First, Zhu et al. [50] reported that the IncRNA LncBRM promoted the self-renewal of liver cancer stem cells by stimulating yes-associated protein 1 , and showed that LncSox4 induced the self-renewal of liver cancer cells with stemness via the STAT3 pathway [50,51]. The IncRNA LncTCF7 promoted the activation of the TCF7 
transcriptional promoter and the Wnt signaling pathway via recruitment of the SWI/SNF complex, thereby inducing the stemness of cancer cells [52].

\section{Tumor suppression}

DNA damage triggered by external factors such as chemical insults can lead to deleterious changes in cellular signaling systems and the accumulation of DNA damage, which can induce tumor progression [53]. IncRNA MEG3 (maternally expressed gene 3 ) activates p53, a tumor suppressor that plays an important role in DNA damage response [54]. The IncRNA PANDA inhibits the expression of pro-apoptotic genes and inhibits DNA damage-induced apoptosis by binding to the transcription factor NF-YA [55]. DNA damage induces the expression of IncRNA-p21 by p53 during cell cycle arrest [56]. The IncRNA Pint is also involved in p53 activity [57]. DNA damage induces the transcription of IncRNA-DINO by p53 to regulate the stress response [58]. In addition, IncRNA CUPID1 and CUPID2 are known mediate the stress response caused by DNA damage during the progression of breast cancer [59]. The IncRNA LED inhibits tumor formation in cell cycle arrest mediated by $p 53$ [60]. The IncRNA NBR2 inhibited cancer cell proliferation by promoting AMPK activity under energy stress, and the knockdown of IncRNA NBR2 induced cancer cell growth and proliferation [61]. In addition, the IncRNA FILNC1 inhibited tumors related to Myc [62].

\section{LncRNAs as diagnostic and prognostic biomarkers}

The IncRNAs can be detected in body fluids such as blood, urine, breast milk, cerebrospinal fluid, and bronchial lavage [64]. The widespread detection of IncRNAs in multiple tissues and fluids suggests their potential application as diagnostic and prognostic biomarkers in various cancers [64,65]. The use of IncRNAs as diagnostic biomarkers has attracted increased attention lately, and several candidate IncRNAs have been studied. Below, we analyze recently discovered IncRNAs based on the cancer type and summarize them in Table 1.

\section{Liver cancer}

The expression of the IncRNA ZNF385D-AS2 (zinc finger protein 385D antisense RNA 2) was analyzed in 303 patients diagnosed with liver cancer using data from The Cancer Genome Atlas-Liver Hepatocellular Carcinoma (TCGA-LIHC). Its expression was decreased in the tissues of liver cancer patients. In addition, the expression of ZNF385D-AS2 was lower in women than in men, and a low level of ZNF385DAS2 was significantly correlated with the tumor-node metastasis (TNM) and clinical stage. Also, patients diagnosed with liver cancer expressing low levels of ZNF385D-AS2 manifested decreased overall survival (OS) rates than those with a high degree of expression [66]. The levels of IncRNA D16366 were also lower in the tissues and serum of HCC patients than in normal controls. For D16366, the area under the curve (AUC) was 0.752 , and the sensitivity and the specificity were $65.5 \%$ and $84.6 \%$, respectively, which strongly support its diagnostic and prognostic value in liver cancer [67].

The expression of nine IncRNAs (SNHG1, SNHG12, LINC00511, HCG18, FGD5-AS1, CERS6-AS1, NUTM2A-AS1, SNHG16, and ASB16-AS1) in HCC patients was analyzed along with survival rates. All the nine IncRNAs showed significantly higher expression in HCC patients than in healthy controls. The prognosis of patients with HCC correlated strongly with the expression of these IncRNAs [68]. The IncRNA SNHG11 was also highly expressed in HCC patients and thereby induced HCC proliferation and migration [69].

The expression of IncRNA MINCR (MYC-induced long non-coding RNA) in the tissues of patients with primary HCC was higher than in adjacent normal tissues. The expression of MINCR correlated with the TNM stage, lymph node metastasis, and cirrhosis. Additionally, HCC patients with increased expression of MINCR had a lower 3-year survival rate than patients with low expression [70].

\section{Lung cancer}

The expression of IncRNA JPX was upregulated in the metastatic tissues of patients with lung cancer. Also, JPX upregulated Twist1 expression and activated Wnt/ $\beta$-catenin signals to induce EMT progression and promote lung cancer cell invasion [71]. The expression of the IncRNA PSMA3-AS1 (PSMA3 antisense RNA 1) was also upregulated in lung cancer tissues and cell lines, and was positively correlated with clinical stage and metastasis. The overexpression of PSMA3-AS1 resulted in poor prognosis of lung cancer patients, and knockdown of PSMA3-AS1 inhibited the proliferation, migration, and invasion of lung cancer cells [72].

The IncRNA DANCR (Differentiation Antagonizing Non-Protein Coding RNA) was highly expressed in terminal lung cancer tissues and aggressive lung cancer cells. In addition, DANCR knockdown reduced cancer cell growth in tumor xenograft models in vivo [73]. The expression of IncRNA TUC338 (transcribed ultraconserved element 338) was also higher in lung cancer than in normal tissues, and the survival time of lung cancer patients correlated with the expression of TUC338. In addition, the inhibition of TUC338 decreased invasiveness, and the overexpression of TUC338 increased lung cancer cell activity and invasiveness [75].

In another study, Zhou et al. [75] confirmed that the IncRNA-DLEU2 (deleted in lymphocytic leukaemia 2) was highly expressed in NSCLC tissues and cell lines, and showed that the expression of DLEU2 correlated with the OS rate of NSCLC patients. Knockdown of DLEU2 inhibited proliferation, invasion, and migration in lung cancer cell lines as well as inhibited tumor growth and metastasis in vivo. The IncRNA AC020978 was also upregulated in NSCLC and was significantly correlated with poor clinical outcomes. Interestingly, 
Table 1. LncRNA with potential as a diagnostic marker in clinical samples

\begin{tabular}{|c|c|c|c|}
\hline Cancer type & IncRNA & IncRNA in clinical samples & Reference \\
\hline \multirow[t]{2}{*}{ Liver cancer } & ZNF385D-AS2, D16366 & Low expression in HCC tissues & {$[66,67]$} \\
\hline & $\begin{array}{l}\text { SNHG1, SNHG12, LINC00511, HCG18, } \\
\text { FGD5-AS1, CERS6-AS1, NUTM2A-AS1, } \\
\text { SNHG16, ASB16-AS1, SNHG11, MINCR }\end{array}$ & High expression in $\mathrm{HCC}$ tissues & [68-70] \\
\hline \multirow[t]{6}{*}{ Lung cancer } & $\mathrm{JPX}$ & $\begin{array}{l}\text { High expression in metastatic lung cancer } \\
\text { tissues }\end{array}$ & [71] \\
\hline & DANCR & $\begin{array}{l}\text { High expression in terminal lung cancer } \\
\text { tissues }\end{array}$ & [73] \\
\hline & PSMA3-AS1, TUC338 & High expression in lung cancer tissue & {$[72,74]$} \\
\hline & DLEU2, AC020978 & High expression in NSCLC tissues & {$[75,76]$} \\
\hline & $\begin{array}{l}\text { SFTA1P, LINC01272, GATA6-AS1, } \\
\text { MIR3945HG, LINC01314 }\end{array}$ & High expression in LUSC tissues & {$[76]$} \\
\hline & LINC01572 & Low expression in LUSC tissues & {$[77]$} \\
\hline \multirow[t]{2}{*}{ Gastric cancer } & PTCSC3 & Low plasma levels in patients & [78] \\
\hline & $\begin{array}{l}\text { NEAT1, AK023391, MIR4435-2HG, } \\
\text { MAGI2-AS3 }\end{array}$ & High expression in cancer tissues & [79-82] \\
\hline \multirow[t]{2}{*}{ Colorectal cancer } & $\begin{array}{l}\text { SNHG16, CACS15, CYTOR, MALAT1, } \\
\text { TUG1, NEAT1, MIR17HG, H19 }\end{array}$ & High expression in CRC tissues & [83-85] \\
\hline & MEG3 & Low expression in CRC tissues & {$[86]$} \\
\hline \multirow[t]{4}{*}{ Breast cancer } & FAM83H-AS1, IncRNA-ATB & High serum levels in breast cancer patients & {$[87]$} \\
\hline & LINC0092, C2orf71 & Low expression in breast cancer tissues & {$[88]$} \\
\hline & 362 & $\begin{array}{l}\text { High expression in ER-positive breast cancer } \\
\text { tissues }\end{array}$ & [89] \\
\hline & NFIA-AS1 & $\begin{array}{l}\text { Low expression in ER-positive breast cancer } \\
\text { tissues }\end{array}$ & [89] \\
\hline \multirow[t]{3}{*}{ Bladder cancer } & PCAT6, HOTAIR & High expression in cancer tissues & {$[90,91]$} \\
\hline & UCA1 & $\begin{array}{l}\text { High levels in urine and serum of bladder } \\
\text { cancer patients }\end{array}$ & [91] \\
\hline & GAS5 & Low expression in cancer tissues & [91] \\
\hline Pancreatic cancer & UFC1 & High serum levels in patients & {$[92]$} \\
\hline Cervical cancer & FALEC & High plasma levels in patients & [93] \\
\hline \multirow[t]{2}{*}{ Ovarian cancer } & $\begin{array}{l}\text { ACTA2-AS1, CARD8-AS1, HHIP-AS1, } \\
\text { HOTAIRM1, LINC00605, LINC01503, } \\
\text { LINC01547, MIR155HG, OTUD6B-AS1 }\end{array}$ & High probability in low expression patients & [94] \\
\hline & $\begin{array}{l}\text { HCP5, ITGB2-AS1, LINC00324, MIR31HG, } \\
\text { PSMG3-AS1, ZBED5-AS1, SH3PXD2A- } \\
\text { AS1 }\end{array}$ & High probability in high expression patients & \\
\hline Osteosarc-oma & TP73-AS1 & High expression in osteosarcoma tissues & [95] \\
\hline Laryngeal carcinoma & IncRNA-ATB & $\begin{array}{l}\text { High expression in laryngeal carcinoma } \\
\text { tissues }\end{array}$ & [96] \\
\hline Brain tumor & HOTAIR & High serum levels in brain tumor patients & [97] \\
\hline
\end{tabular}

LncRNA, long non-coding RNA; HCC, hepatocellular carcinoma; NSCLC, non-small cell lung cancer; LUSC, lung squamous cell carcinoma; CRC, colorectal cancer; ER, estrogen receptor.

the level of AC020978 was found to be an independent prognostic predictor in NSCLC patients [76].

By analyzing abnormally expressed IncRNAs using RNA-sequencing data from lung squamous cell carcinoma (LUSC) patients, the levels of IncRNAs SFTA1P, LINC01272, GATA6-AS1, and MIR3945HG were shown to be significantly correlated with the survival of LUSC patients. In addition, LINC01572 and LINC01314 served as markers for distinguishing between early and late stages of LUSC [77].

\section{Gastric cancer}

In patients with gastric cancer (GC), the level of IncRNA PTCSC3 (papillary thyroid carcinoma susceptibility candidate 3 ) in the plasma was shown to be down-regulated compared with healthy controls, and the expression of PTCSC3 was upregulated on the day of discharge compared with pretreatment levels. In addition, patients with low plasma levels of PTCSC3 had significantly lower OS rates than those with high plasma levels. PTCSC3 also inhibited the proliferation, invasion, and migration of GC cells [78].

The IncRNA NEAT1 was highly expressed in GC cells and tissues, and knockdown of NEAT1 was shown to inhibit the 
invasion and metastasis of GC cells [79].

The expression of IncRNA AK023391 was likewise significantly upregulated in GC tissue samples and cell lines compared with normal tissues, and a high degree of AK023391 expression correlated with low survival rates in GC patients. Knockdown of AK023391 inhibited the proliferation and invasion of GC cells both in vitro and in vivo, and its overexpression reversed this phenomenon [80]. The expression of IncRNA MIR4435-2HG (microRNA 4435-2HG) was also significantly upregulated in GC tissues compared with normal gastric tissues and the increased expression of MIR4435$2 \mathrm{HG}$ was associated with poor clinical pathology. In addition, the overexpression of MIR4435-2HG enhanced the proliferation and invasive ability of GC cells [81].

The IncRNA MAGI2-AS3 (MAGI2 Antisense RNA 3) was also highly expressed in GC tissues, and overexpression of MAGI2-AS3 was found to be correlated with the poor prognosis of GC patients. Additionally, a multivariate analysis revealed that IncRNA MAGI2-AS3 was significantly correlated with the OS and disease-free survival (DFS) rates of GC patients [82].

\section{Colorectal cancer}

High levels of IncRNA SNHG16 were associated with tumor progression and proliferation in patients with colorectal cancer (CRC) [83]. Additionally, several IncRNAs including CACS15, CYTOR, MALAT1, TUG1, NEAT1, and MIR17HG were also suggested as potential prognostic markers in patients with CRC [84].

The expression of IncRNA H19 was higher in CRC tissues compared with normal tissues. In addition, CRC patients with high $\mathrm{H} 19$ expression showed significantly lower survival rates than those with low $\mathrm{H} 19$ expression [85].

However, the levels of IncRNA MEG3 were significantly reduced in CRC tissues, serum samples, and cell lines. In addition, serum MEG3 levels were shown to affect the prognosis of CRC patients, and Kaplan-Meier (KM) survival curve analysis suggests that CRC patients with high MEG3 levels had substantially higher OS than those carrying low levels of MEG3 [86].

\section{Breast cancer}

Serum levels of the IncRNA FAM83H-AS1 (FAM83H antisense RNA 1) and IncRNA-ATB were found to be higher in breast cancer patients than in healthy controls. As shown by the receiver operating characteristic (ROC) curve, the area under the curve value of IncRNA-ATB was higher than that of CA15-3. CA15-3 is a tumor biomarker previously used in the early diagnosis of stage I-II breast cancer. Thus, studies strongly suggest the potential role of IncRNA-ATB as a diagnostic biomarker. In addition, the levels of IncRNA FAM83HAS1 showed a significant correlation with TNM stage, tumor size, and lymph node metastasis, suggesting that FAM83HAS1 may have prognostic value [87].
The IncRNAs LINC0092 and C2orf71 are associated with good prognosis in breast cancer patients [88]. In addition, the expression of IncRNA 362 was higher in estrogen receptor (ER)-positive breast cancer compared with normal tissues, and the expression of NFIA-AS1 was lower in ER-positive breast cancer [89].

\section{Other cancer species}

The IncRNA PCAT6 (prostate cancer-associated transcript 6) was strongly expressed in the tissues and serum of patients with bladder cancer (BC) than in healthy controls. In addition, the expression of PCAT6 was significantly correlated with tumor size, TNM stage, proliferation, and degree of metastasis. KM survival analysis showed that $\mathrm{BC}$ patients with high PCAT6 expression had worse OS rates and progression-free survival (PFS) than those with low PCAT6 expression [90]. Additionally, the results of a meta-analysis showed that IncRNA UCA1 has diagnostic value in BC patients. The abnormal expression of IncRNAs HOTAIR and GAS5 in BC patients was also correlated with poor disease-free/recurrence-free/disease-specific survival [91].

Serum levels of the IncRNA UFC1 in patients diagnosed with $\mathrm{PC}$ were much higher than in normal subjects and the high UFC1 expression was correlated with increased metastasis and a more severe clinical stage. In addition, KM survival analysis showed that PC patients with high UFC1 expression had shorter progression-free survival and OS than those with low UFC1 expression [92].

The level of the IncRNA FALEC in the blood plasma of cervical cancer patients was significantly higher than in normal patients, and also showed a significant correlation with metastasis and tumor size [93].

Sixteen IncRNAs (ACTA2-AS1, CARD8-AS1, HCP5, HHIPAS1, HOTAIRM1, ITGB2-AS1, LINC00324, LINC00605, LINC01503, LINC01547, MIR31HG, MIR155HG, OTUD6BAS1, PSPXD2A1, SH3PMG3-AS1, SH3, and ZBED5-AS1) were found to be significantly correlated with the OS rate of patients with ovarian cancer (OC) [94].

The expression of IncRNA TP73-AS1 was elevated in osteosarcoma tissues and cell lines. Additionally, the expression of TP73-AS1 correlated with tumor size, degree of metastasis, and histological grade in patients with osteosarcoma, suggesting that TP73-AS1 may be a useful prognostic indicator [95].

The expression of IncRNA-ATB was significantly elevated in the cancer tissues of patients with laryngeal carcinoma compared with normal tissues. Interestingly, the IncRNA-ATB expression was correlated with T-grade and clinical stage [96].

The level of IncRNA HOTAIR in the serum of patients with glioblastoma multiforme (GBM), a type of brain tumor, was significantly higher than that of control groups [97]. 


\section{LncRNAs implicated in sex hormone signaling} Sex hormones are one of the representative endogenous factors contributing to gender-specific incidence and development of cancer. In this section we review the role of sex hormones in regulating the function of cancer-related IncRNAs (Table 2).

\section{Estrogen-regulated IncRNAs}

Previous studies have reported a close correlation between the abnormal expression of IncRNAs in breast cancer with cancer progression and proliferation $[98,99]$. Below, we summarize some of the IncRNAs interacting with estrogen or ER in breast cancer.

Overexpression of the IncRNA HOTAIR induced proliferation of breast cancer cells. In addition, decreased expression of HOTAIR reduced the survival rate of breast cancer cells and diminished the proliferation of tamoxifen-resistant cells. Activation of ERs directly inhibits HOTAIR, and upregulation of HOTAIR induces tamoxifen resistance [100].
The expression of the IncRNA ERINA (estrogen-inducible IncRNA) was particularly high in ER-positive breast cancer tissues. ERINA knockdown inhibited cell cycle progression and cell proliferation in breast cancer cell cultures. These findings were consistent with a xenograft model in which ERINA knockdown reduced tumor growth. However, the overexpression of ERINA promoted the proliferation and growth of breast cancer cells. Fang's group reported that the intronic ER-binding site acted as an enhancer in the transactivation of ERINA. The same group also identified ERINA as a IncRNA binding with estrogen and ER [101].

The expression of the IncRNA TROJAN was remarkably high in ER-positive breast cancer. TROJAN promoted the proliferation of breast cancer cells and decreased the survival rate of patients with ER-positive breast cancer [102]. The level of the IncRNA TMPO-AS1 was positively correlated with estrogen receptor 1 (ESR1) expression via stabilization of ESR1 mRNA. Upregulation of TMPO-AS1 expression induced the proliferation of ER-positive breast cancer cells via

Table 2. Sex hormone-regulated IncRNA and its role in cancer

\begin{tabular}{|c|c|c|c|c|c|}
\hline $\begin{array}{l}\text { Sex hormone } \\
\text { receptor }\end{array}$ & IncRNA & Cancer type & $\begin{array}{l}\text { Relation with sex } \\
\text { hormone receptor }\end{array}$ & Role in cancer & Reference \\
\hline \multirow[t]{9}{*}{ ER } & HOTAIR & Breast cancer & Inhibited by ER & $\begin{array}{l}\text { Induce proliferation and } \\
\text { tamoxifen resistance }\end{array}$ & {$[100]$} \\
\hline & ERINA & & $\begin{array}{l}\text { Inhanced transactivation } \\
\text { by ER }\end{array}$ & Induce proliferation and growth & [101] \\
\hline & $\begin{array}{l}\text { TROJAN, } \\
\text { MIAT }\end{array}$ & & $\begin{array}{l}\text { High in ER-positive breast } \\
\text { cancer }\end{array}$ & Induce proliferation & {$[102,105]$} \\
\hline & TMPO-AS1 & & Stabilize ESR1 mRNA & Induce proliferation & [103] \\
\hline & TCL6 & & $\begin{array}{l}\text { Low in ER-positive breast } \\
\text { cancer }\end{array}$ & $\begin{array}{l}\text { High probability in high } \\
\text { expression patients }\end{array}$ & [104] \\
\hline & $\mathrm{H} 19$ & Thyroid cancer & $\begin{array}{l}\text { Promoted transcription } \\
\text { by ER } \beta\end{array}$ & $\begin{array}{l}\text { High probability in low } \\
\text { expression patients }\end{array}$ & [106] \\
\hline & MALAT1 & Lung cancer & $\begin{array}{l}\text { Increased expression } \\
\text { by ER } \beta\end{array}$ & $\begin{array}{l}\text { Induce vasculogenic mimicry } \\
\text { formation and invasion }\end{array}$ & [107] \\
\hline & HOTAIR & Renal cancer & Inhanced by ER & $\begin{array}{l}\text { Induce proliferation and } \\
\text { invasion }\end{array}$ & [108] \\
\hline & LINC00263 & $\begin{array}{l}\text { Lung cancer, } \\
\text { Colorectal } \\
\text { cancer, Renal } \\
\text { cancer }\end{array}$ & Inhibited by ER & $\begin{array}{l}\text { High expression in cancer } \\
\text { tissue }\end{array}$ & [109] \\
\hline \multirow[t]{8}{*}{ AR } & ARLNC1 & Prostate cancer & $\begin{array}{l}\text { Induced by AR, stabilize AR } \\
\text { transcription }\end{array}$ & Induce proliferation and growth & [113] \\
\hline & LINC00844 & & $\begin{array}{l}\text { Regulate the transcriptional } \\
\text { regulation of androgen- } \\
\text { related genes }\end{array}$ & $\begin{array}{l}\text { Induce proliferation and } \\
\text { progression }\end{array}$ & [114] \\
\hline & PRCAT38 & & $\begin{array}{l}\text { Increased through AR } \\
\text { transactivation }\end{array}$ & Induce proliferation & [115] \\
\hline & LINC00304 & & Inhibit AR & $\begin{array}{l}\text { Induce proliferation and cell } \\
\text { cycle progression }\end{array}$ & [116] \\
\hline & SARCC & Renal cancer & Inhibit activity of AR & Suppress tumor & [117] \\
\hline & HOTAIR & & Promote activity of AR & Induce tumor angiogenesis & [118] \\
\hline & SLNCR & Melanoma & Combined with AR & Induce proliferation & [119] \\
\hline & PART1 & $\begin{array}{l}\text { Lung cancer, } \\
\text { Colon cancer }\end{array}$ & Induced by androgen & Promote progression & {$[120,121]$} \\
\hline
\end{tabular}

LncRNA, Long non-coding RNA; ER, estrogen receptor; ESR1, estrogen receptor 1 gene; AR, androgen receptor. 
stabilization of ESR1 [103].

In breast cancer, the expression of the IncRNA TCL6 (T Cell Leukemia/Lymphoma 6) was correlated with the presence or absence of ER and progesterone receptor (PR). In particular, progesterone receptor-negative patients with a low expression of TCL6 showed a poor prognosis [104].

The IncRNA MIAT was significantly higher in MCF-7, an ER-positive breast cancer cell line, and in ER-positive breast cancer tissue samples. In addition, the MIAT expression was increased in a concentration-dependent manner following the activation of estrogen signaling pathway upon treatment with diethylstilbestrol (DES), an ER agonist [105].

The IncRNAs and ER interact in cancers of breast, thyroid, and lung, as well as CRC and renal cell carcinoma (RCC). The IncRNA H19 was highly expressed in papillary thyroid cancer stem cells (PTCSC) and papillary thyroid cancer (PTC) tissue samples. Additionally, the OS rate of patients with PTC was decreased as the expression of $\mathrm{H} 19$ increased. The transcription of $\mathrm{H} 19$ was significantly promoted by estradiol (E2) and ER $\beta$, and as a result, estradiol increased the expression of $\mathrm{H} 19$ [107].

Yu et al. [107] showed that the IncRNA MALAT1 expression was related to the molecular mechanism of the second estrogen receptor, ER $\beta$. ER $\beta$ increased MALAT1 expression by directly binding to the estrogen response element located at the MALAT1 promoter. ER $\beta$ induced vasculogenic mimicry and cancer cell invasion in NSCLC by altering the ER $\beta /$ MALAT1/miR145-5p/NEDD9 signaling pathway.

Interestingly, the IncRNA HOTAIR is also regulated by ER $\beta$ and antagonizes several microRNAs, thereby modulating the expression of genes such as vimentin, ZEB1, and ZEB2 to induce the proliferation and invasion of RCC cells [108].

The expression of the IncRNA LINC00263 was higher in male patients than in female patients diagnosed with lung adenocarcinoma, CRC, or RCC. LINC00263 showed a strong negative correlation with ESR1, and the expression of LINC00263 tended to decrease with estrogen treatment. Further, ligand-activated ER inhibited the function of LINC00263 by blocking the NF-кB pathway. The inhibitory effects of estrogen on LINC00263 induced differences between males and females in various cancers [109].

\section{Androgen-regulated IncRNAs}

Studies suggested that androgen signaling of PC is affected by several IncRNAs interacting directly with androgen receptors $(A R)$ to regulate PC cell proliferation [110-112]. Below, we summarize a few IncRNAs interacting with androgen or AR in PC (Table 2).

The IncRNA ARLNC1 (AR-regulated long noncoding RNA 1) was not only induced by $A R$, but also stabilized $A R$ transcription via RNA-RNA interactions. Knockdown of ARLNC1 decreased the expression of $A R$ and inhibited the growth of PC cells [113].

Lingadahalli et al. [114] used gene expression profiling to demonstrate the effect of IncRNA LINC00844 in the transcriptional regulation of androgen-related genes. The findings suggested that LINC00844 may play a key role in the proliferation and progression of $\mathrm{PC}$ cells by regulating the transcriptional network of $A R$.

In PC cells, the expression of IncRNA PRCAT38 (prostate cancer-related transcript 38) was increased via AR transactivation. PRCAT38 was co-regulated with transmembrane protease serine 2 (TMPRSS2), which is another androgen regulating gene, via similar enhancers [115]. The IncRNA LINC00304 has been shown to be related to cell cycle progression and PC cell proliferation. In addition, it was confirmed that LINC00304 is a direct target of AR [116].

In RCC and melanoma, IncRNAs have been shown to interact with $\mathrm{AR}$ and regulate the progression, proliferation, and malignancy of cancer cells. The IncRNA SARCC (suppressing androgen receptor in renal cell carcinoma) suppressed RCC tumors by inhibiting the activity of AR. SARCC inhibited $A R$ after transcription and blocked RCC development by regulating the AR/miR-143-3p signaling pathway [117]. Additionally, the IncRNA HOTAIR formed a feedback loop with AR to promote each other's activities, thereby inducing tumor angiogenesis in RCC. A high expression of HOTAIR in patients with RCC was associated with poor prognosis [118].

The IncRNA SLNCR bound to AR regulated the transcription of several growth regulatory genes and increased melanoma proliferation. These findings explain the higher incidence and rapid progression of melanoma in men compared with women [119].

Additionally, the IncRNA PART1 (prostate androgen regulated transcript 1) enhanced the progression of LUSC via interaction with miR-185-5p and sine oculis homeobox homolog 1 (Six1). It also promoted the malignant progression of colon cancer by regulating the expression of miR-150-5p and leucine-rich $\alpha$-2-glycoprotein-1 (LRG1) [120,121].

\section{CONCLUSION}

In this review, the actions of a variety of IncRNAs were discussed and their potential as cancer biomarkers was analyzed. As shown in Table 1, several IncRNAs induce cancer and malignancy via multiple mechanisms of tumorigenesis such as immune escape, metabolic dysfunction, regulation of growth and proliferation, and promotion of oncogene expression. In addition, many IncRNAs induce cancer cell metastasis by inducing EMT and stemness. Conversely, several other IncRNAs may act as tumor suppressors.

Numerous studies reported that IncRNA levels in the tissues and serum of normal patients differed from those of patients diagnosed with cancers of liver, lung, stomach, breast, and several other carcinomas. In many cases their expression levels showed a significant correlation with patient survival rates. In addition, many recent findings of IncRNAs have already been investigated or should be explored further 


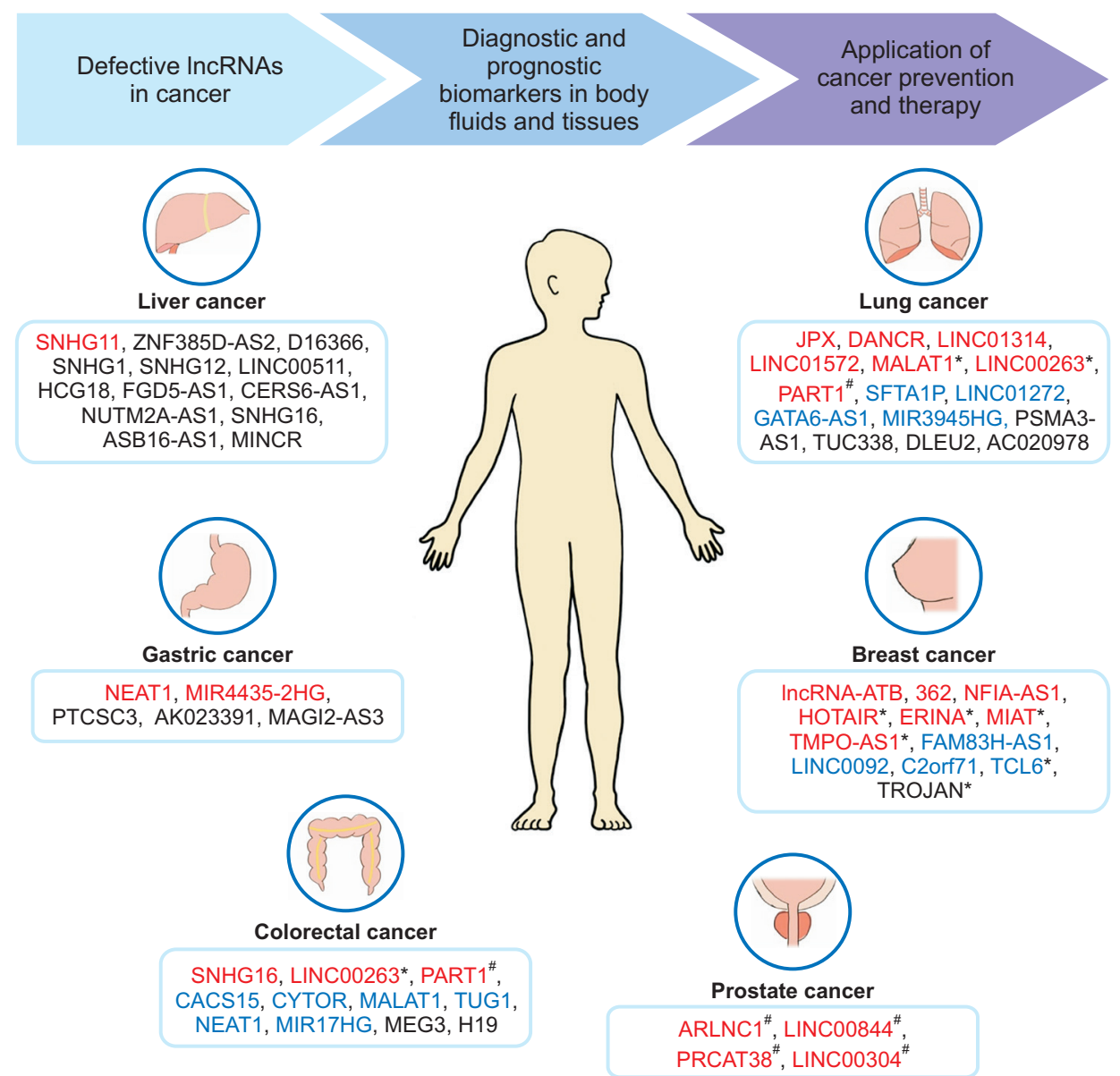

Figure 1. The potential application of IncRNAs in cancer diagnosis, prevention and therapy. These summarized IncRNAs in various types of cancer were categorized according to the application of biomarkers for diagnosis or prognosis. The IncRNAs written in red letters represents the biomarkers for diagnosis; blue letters, for prognosis; black letters, for diagnosis and prognosis. In addition, their correlations with sex hormones were presented: *IncRNAs implicated in estrogen; "IncRNAs implicated in androgen. IncRNA, long non-coding RNA; ZNF385D-AS2, zinc finger protein 385D antisense RNA 2; MIR4435-2HG, microRNA 4435-2HG; PTCSC3, papillary thyroid carcinoma susceptibility candidate 3; PART1, prostate androgen regulated transcript 1; MALAT1, metastasis-associated lung adenocarcinoma transcript 1; MEG3, maternally expressed gene 3; DANCR, Differentiation Antagonizing Non-Protein Coding RNA; DLEU2, deleted in lymphocytic leukaemia 2; HOTAIR, HOX transcript antisense RNA; ERINA, estrogen-inducible IncRNA; FAM83H-AS1, FAM83H antisense RNA 1; C2orf71, chromosome 2 open reading frame 71; TCL6, T Cell Leukemia/ Lymphoma 6; ARLNC1, AR-regulated long noncoding RNA 1; PRCAT38, prostate cancer-related transcript 38.

to determine the mechanisms of regulation by sex hormones in sex-specific cancer. Thus, the regulatory IncRNAs should be investigated to determine their role in various types of cancer in the future. In this review, we presented the potential of various IncRNAs that can be used as biomarkers for diagnosis and prognosis and as targets for treatment and prevention of cancer, and also looked at IncRNAs that correlate with sex hormones (Fig. 1). Studies investigating various cancers and the sex-specific effects should focus on changes in the expression of IncRNAs using cell cultures and animal models, as well as clinical samples if available. The development of technologies based on IncRNAs as diagnostic markers or therapeutic targets may represent a significant step forward in the management of many types of cancer.

\section{ACKNOWLEDGMENTS}

This research was supported by Duksung Women's University Research Grants 2019.

\section{CONFLICTS OF INTEREST}

No potential conflicts of interest were disclosed.

\section{ORCID}

Hye Kyung Song, https://orcid.org/0000-0001-8033-5596 Sun Young Kim, https://orcid.org/0000-0002-5994-8889 


\section{REFERENCES}

1. Ponting CP, Belgard TG. Transcribed dark matter: meaning or myth? Hum Mol Genet 2010;19:R162-8.

2. Djebali S, Davis CA, Merkel A, Dobin A, Lassmann T, Mortazavi $A$, et al. Landscape of transcription in human cells. Nature 2012;489:101-8.

3. Wapinski O, Chang HY. Long noncoding RNAs and human disease. Trends Cell Biol 2011;21:354-61.

4. Brosnan CA, Voinnet $O$. The long and the short of noncoding RNAs. Curr Opin Cell Biol 2009;21:416-25.

5. Shi T, Gao G, Cao Y. Long noncoding RNAs as novel biomarkers have a promising future in cancer diagnostics. Dis Markers 2016;2016:9085195.

6. Han Li C, Chen Y. Small and long non-coding RNAs: novel targets in perspective cancer therapy. Curr Genomics 2015;16:319-26.

7. Huang Y, Liu N, Wang JP, Wang YQ, Yu XL, Wang ZB, et al. Regulatory long non-coding RNA and its functions. J Physiol Biochem 2012;68:611-8.

8. Zhang H, Chen Z, Wang X, Huang Z, He Z, Chen Y. Long non-coding RNA: a new player in cancer. $J$ Hematol Oncol 2013;6:37.

9. Qiu MT, Hu JW, Yin R, Xu L. Long noncoding RNA: an emerging paradigm of cancer research. Tumour Biol 2013;34:613-20.

10. Kirsch-Volders M, Bonassi S, Herceg Z, Hirvonen A, Möller L, Phillips DH. Gender-related differences in response to mutagens and carcinogens. Mutagenesis 2010;25:213-21.

11. Dorak MT, Karpuzoglu E. Gender differences in cancer susceptibility: an inadequately addressed issue. Front Genet 2012;3:268.

12. Hanahan D, Weinberg RA. Hallmarks of cancer: the next generation. Cell 2011;144:646-74.

13. Gabriele L, Buoncervello M, Ascione B, Bellenghi M, Matarrese $\mathrm{P}$, Carè $\mathrm{A}$. The gender perspective in cancer research and therapy: novel insights and on-going hypotheses. Ann Ist Super Sanita 2016;52:213-22.

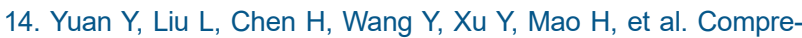
hensive characterization of molecular differences in cancer between male and female patients. Cancer Cell 2016;29:71122.

15. Locker GY, Hamilton S, Harris J, Jessup JM, Kemeny N, Macdonald JS, et al. ASCO 2006 update of recommendations for the use of tumor markers in gastrointestinal cancer. J Clin Oncol 2006;24:5313-27.

16. Bast RC Jr, Xu FJ, Yu YH, Barnhill S, Zhang Z, Mills GB. CA 125: the past and the future. Int J Biol Markers 1998;13:179-87.

17. Yao RW, Wang Y, Chen LL. Cellular functions of long noncoding RNAs. Nat Cell Biol 2019;21:542-51.

18. Batista PJ, Chang HY. Long noncoding RNAs: cellular address codes in development and disease. Cell 2013;152:1298-307.

19. Yuan JH, Yang F, Wang F, Ma JZ, Guo YJ, Tao QF, et al. A long noncoding RNA activated by TGF- $\beta$ promotes the invasionmetastasis cascade in hepatocellular carcinoma. Cancer Cell
2014;25:666-81.

20. Heward JA, Lindsay MA. Long non-coding RNAs in the regulation of the immune response. Trends Immunol 2014;35:40819.

21. Ranzani V, Rossetti G, Panzeri I, Arrigoni A, Bonnal RJ, Curti S, et al. The long intergenic noncoding RNA landscape of human lymphocytes highlights the regulation of $T$ cell differentiation by linc-MAF-4. Nat Immunol 2015;16:318-25.

22. Jiang R, Tang J, Chen Y, Deng L, Ji J, Xie Y, et al. The long noncoding RNA Inc-EGFR stimulates T-regulatory cells differentiation thus promoting hepatocellular carcinoma immune evasion. Nat Commun 2017;8:15129.

23. Chen C, He W, Huang J, Wang B, Li H, Cai Q, et al. LNMAT1 promotes lymphatic metastasis of bladder cancer via CCL2 dependent macrophage recruitment. Nat Commun 2018;9:3826.

24. Leucci E, Vendramin R, Spinazzi M, Laurette P, Fiers M, Wouters $\mathrm{J}$, et al. Melanoma addiction to the long non-coding RNA SAMMSON. Nature 2016;531:518-22.

25. Shih JW, Chiang WF, Wu ATH, Wu MH, Wang LY, Yu YL, et al. Long noncoding RNA LncHIFCAR/MIR31HG is a HIF-1 $\alpha$ co-activator driving oral cancer progression. Nat Commun 2017;8:15874.

26. Huang JZ, Chen M, Chen D, Gao XC, Zhu S, Huang H, et al. A peptide encoded by a putative IncRNA HOXB-AS3 suppresses colon cancer growth. Mol Cell 2017;68:171-84.e6.

27. Trimarchi T, Bilal E, Ntziachristos P, Fabbri G, Dalla-Favera R, Tsirigos A, et al. Genome-wide mapping and characterization of Notch-regulated long noncoding RNAs in acute leukemia. Cell 2014;158:593-606.

28. Hu X, Feng Y, Zhang D, Zhao SD, Hu Z, Greshock J, et al. A functional genomic approach identifies FAL1 as an oncogenic long noncoding RNA that associates with BMI1 and represses p21 expression in cancer. Cancer Cell 2014;26:344-57.

29. Zheng GX, Do BT, Webster DE, Khavari PA, Chang HY. DicermicroRNA-Myc circuit promotes transcription of hundreds of long noncoding RNAs. Nat Struct Mol Biol 2014;21:585-90.

30. Tseng YY, Moriarity BS, Gong W, Akiyama R, Tiwari A, Kawakami $\mathrm{H}$, et al. PVT1 dependence in cancer with MYC copy-number increase. Nature 2014;512:82-6.

31. Kim T, Cui R, Jeon YJ, Lee JH, Lee JH, Sim H, et al. Longrange interaction and correlation between $\mathrm{MYC}$ enhancer and oncogenic long noncoding RNA CARLo-5. Proc Natl Acad Sci USA. 2014;111:4173-8.

32. Xiang JF, Yin QF, Chen T, Zhang Y, Zhang XO, Wu Z, et al. Human colorectal cancer-specific CCAT1-L IncRNA regulates long-range chromatin interactions at the MYC locus. Cell Res 2014;24:513-31.

33. Hung CL, Wang LY, Yu YL, Chen HW, Srivastava S, Petrovics $\mathrm{G}$, et al. A long noncoding RNA connects C-Myc to tumor metabolism. Proc Natl Acad Sci USA 2014;111:18697-702.

34. Hay ED. An overview of epithelio-mesenchymal transformation. Acta Anat (Basel) 1995;154:8-20.

35. Kalluri R, Weinberg RA. The basics of epithelial-mesenchymal transition. J Clin Invest 2009;119:1420-8. 
36. Nieto MA. Epithelial-Mesenchymal Transitions in development and disease: old views and new perspectives. Int $\mathrm{J}$ Dev Biol 2009;53:1541-7.

37. Gupta RA, Shah N, Wang KC, Kim J, Horlings HM, Wong DJ, et al. Long non-coding RNA HOTAIR reprograms chromatin state to promote cancer metastasis. Nature 2010;464:1071-6.

38. Huarte M. The emerging role of IncRNAs in cancer. Nat Med 2015;21:1253-61.

39. Ottaviani S, Stebbing J, Frampton AE, Zagorac S, Krell J, de Giorgio $A$, et al. TGF- $\beta$ induces miR-100 and miR-125b but blocks let-7a through LIN28B controlling PDAC progression. Nat Commun 2018;9:1845.

40. Huang JF, Guo YJ, Zhao CX, Yuan SX, Wang Y, Tang GN, et al. Hepatitis $B$ virus $X$ protein $(\mathrm{HBx})$-related long noncoding RNA (IncRNA) down-regulated expression by HBx (Dreh) inhibits hepatocellular carcinoma metastasis by targeting the intermediate filament protein vimentin. Hepatology 2013;57:1882-92.

41. Grelet S, Link LA, Howley B, Obellianne C, Palanisamy V, Gangaraju VK, et al. A regulated PNUTS mRNA to IncRNA splice switch mediates EMT and tumour progression. Nat Cell Biol 2017;19:1105-15.

42. Yang Z, Zhou L, Wu LM, Lai MC, Xie HY, Zhang F, et al. Overexpression of long non-coding RNA HOTAIR predicts tumor recurrence in hepatocellular carcinoma patients following liver transplantation. Ann Surg Oncol 2011;18:1243-50.

43. Kim K, Jutooru I, Chadalapaka G, Johnson G, Frank J, Burghardt R, et al. HOTAIR is a negative prognostic factor and exhibits pro-oncogenic activity in pancreatic cancer. Oncogene 2013;32:1616-25.

44. Ren Y, Jia HH, Xu YQ, Zhou X, Zhao XH, Wang YF, et al. Paracrine and epigenetic control of CAF-induced metastasis: the role of HOTAIR stimulated by TGF-ß1 secretion. Mol Cancer 2018;17:5.

45. Ji P, Diederichs S, Wang W, Böing S, Metzger R, Schneider PM, et al. MALAT-1, a novel noncoding RNA, and thymosin beta4 predict metastasis and survival in early-stage non-small cell lung cancer. Oncogene 2003;22:8031-41.

46. Gutschner T, Hämmerle M, Eissmann M, Hsu J, Kim Y, Hung $G$, et al. The noncoding RNA MALAT1 is a critical regulator of the metastasis phenotype of lung cancer cells. Cancer Res 2013;73:1180-9.

47. Prensner JR, lyer MK, Sahu A, Asangani IA, Cao Q, Patel L, et al. The long noncoding RNA SChLAP1 promotes aggressive prostate cancer and antagonizes the SWI/SNF complex. Nat Genet 2013;45:1392-8.

48. Prensner JR, Zhao S, Erho N, Schipper M, Iyer MK, Dhanasekaran SM, et al. RNA biomarkers associated with metastatic progression in prostate cancer: a multi-institutional high-throughput analysis of SChLAP1. Lancet Oncol 2014;15:1469-80.

49. Jiang MC, Ni JJ, Cui WY, Wang BY, Zhuo W. Emerging roles of IncRNA in cancer and therapeutic opportunities. Am J Cancer Res 2019;9:1354-66.
50. Zhu P, Wang Y, Wu J, Huang G, Liu B, Ye B, et al. LncBRM initiates YAP1 signalling activation to drive self-renewal of liver cancer stem cells. Nat Commun 2016;7:13608.

51. Chen ZZ, Huang L, Wu YH, Zhai WJ, Zhu PP, Gao YF. LncSox4 promotes the self-renewal of liver tumour-initiating cells through Stat3-mediated Sox4 expression. Nat Commun 2016;7:12598.

52. Wang Y, He L, Du Y, Zhu P, Huang G, Luo J, et al. The long noncoding RNA IncTCF7 promotes self-renewal of human liver cancer stem cells through activation of Wnt signaling. Cell Stem Cell 2015;16:413-25.

53. Napirei M, Karsunky H, Zevnik B, Stephan H, Mannherz HG, Möröy T. Features of systemic lupus erythematosus in Dnase1deficient mice. Nat Genet 2000;25:177-81.

54. Zhou Y, Zhong Y, Wang Y, Zhang X, Batista DL, Gejman R, et al. Activation of p53 by MEG3 non-coding RNA. J Biol Chem 2007;282:24731-42.

55. Hung T, Wang Y, Lin MF, Koegel AK, Kotake Y, Grant GD, et al. Extensive and coordinated transcription of noncoding RNAs within cell-cycle promoters. Nat Genet 2011;43:621-9.

56. Dimitrova N, Zamudio JR, Jong RM, Soukup D, Resnick R, Sarma K, et al. LincRNA-p21 activates p21 in cis to promote Polycomb target gene expression and to enforce the G1/S checkpoint. Mol Cell 2014;54:777-90.

57. Marín-Béjar O, Marchese FP, Athie A, Sánchez Y, González J, Segura V, et al. Pint lincRNA connects the p53 pathway with epigenetic silencing by the Polycomb repressive complex 2 . Genome Biol 2013;14:R104.

58. Schmitt AM, Garcia JT, Hung T, Flynn RA, Shen Y, Qu K, et al. An inducible long noncoding RNA amplifies DNA damage signaling. Nat Genet 2016;48:1370-6.

59. Betts JA, Moradi Marjaneh M, Al-Ejeh F, Lim YC, Shi W, Sivakumaran $\mathrm{H}$, et al. Long noncoding RNAs CUPID1 and CUPID2 mediate breast cancer risk at $11 \mathrm{q} 13$ by modulating the response to DNA damage. Am J Hum Genet 2017;101:255-66.

60. Léveillé N, Melo CA, Rooijers K, Díaz-Lagares A, Melo SA, Korkmaz G, et al. Genome-wide profiling of p53-regulated enhancer RNAs uncovers a subset of enhancers controlled by a IncRNA. Nat Commun 2015;6:6520.

61. Liu X, Xiao ZD, Han L, Zhang J, Lee SW, Wang W, et al. LncRNA NBR2 engages a metabolic checkpoint by regulating AMPK under energy stress. Nat Cell Biol 2016;18:431-42.

62. Xiao ZD, Han L, Lee H, Zhuang L, Zhang Y, Baddour J, et al. Energy stress-induced IncRNA FILNC1 represses c-Myc-mediated energy metabolism and inhibits renal tumor development. Nat Commun 2017;8:783.

63. Weber JA, Baxter DH, Zhang S, Huang DY, Huang KH, Lee MJ, et al. The microRNA spectrum in 12 body fluids. Clin Chem 2010;56:1733-41.

64. Qu H, Xu W, Huang Y, Yang S. Circulating miRNAs: promising biomarkers of human cancer. Asian Pac J Cancer Prev 2011;12:1117-25.

65. Duttagupta R, Jiang R, Gollub J, Getts RC, Jones KW. Impact of cellular miRNAs on circulating miRNA biomarker signatures. PLoS One 2011;6:e20769. 
66. Zhang Z, Wang S, Liu Y, Meng Z, Chen F. Low IncRNA ZNF385D-AS2 expression and its prognostic significance in liver cancer. Oncol Rep 2019;42:1110-24.

67. Chao Y, Zhou D. IncRNA-D16366 is a potential biomarker for diagnosis and prognosis of hepatocellular carcinoma. Med Sci Monit 2019;25:6581-6.

68. Zhang J, Lou W. A key mRNA-miRNA-IncRNA competing endogenous RNA triple sub-network linked to diagnosis and prognosis of hepatocellular carcinoma. Front Oncol 2020;10:340.

69. Huang W, Huang F, Lei Z, Luo H. LncRNA SNHG11 promotes proliferation, migration, apoptosis, and autophagy by regulating hsa-miR-184/AGO2 in HCC. Onco Targets Ther 2020;13:41321.

70. Lian J, Zhang X, Lu Y, Hao S, Zhang Z, Yang Y. Expression and significance of LncRNA-MINCR and CDK2 mRNA in primary hepatocellular carcinoma. Comb Chem High Throughput Screen 2019;22:201-6.

71. Pan J, Fang S, Tian H, Zhou C, Zhao X, Tian H, et al. IncRNA JPX/miR-33a-5p/Twist1 axis regulates tumorigenesis and metastasis of lung cancer by activating $\mathrm{Wnt} / \beta$-catenin signaling. Mol Cancer 2020;19:9.

72. Li F, Yu L, Zhu J. LncRNA PSMA3-AS1 promotes lung cancer growth and invasion via sponging MiR-4504. Cancer Manag Res 2020;12:5277-83.

73. Zhen Q, Gao LN, Wang RF, Chu WW, Zhang YX, Zhao XJ, et al. LncRNA DANCR promotes lung cancer by sequestering miR-216a. Cancer Control 2018;25:1073274818769849.

74. Zhang YX, Yuan J, Gao ZM, Zhang ZG. LncRNA TUC338 promotes invasion of lung cancer by activating MAPK pathway. Eur Rev Med Pharmacol Sci 2018;22:443-9.

75. Zhou Y, Shi H, Du Y, Zhao G, Wang X, Li Q, et al. IncRNA DLEU2 modulates cell proliferation and invasion of non-small cell lung cancer by regulating miR-30c-5p/SOX9 axis. Aging (Albany NY) 2019;11:7386-401.

76. Hua Q, Mi B, Xu F, Wen J, Zhao L, Liu J, et al. Hypoxia-induced IncRNA-AC020978 promotes proliferation and glycolytic metabolism of non-small cell lung cancer by regulating PKM2/ HIF-1 $\alpha$ axis. Theranostics 2020;10:4762-78.

77. Chen WJ, Tang RX, He RQ, Li DY, Liang L, Zeng JH, et al. Clinical roles of the aberrantly expressed IncRNAs in lung squamous cell carcinoma: a study based on RNA-sequencing and microarray data mining. Oncotarget 2017;8:61282-304.

78. Zhang G, Chi N, Lu Q, Zhu D, Zhuang Y. LncRNA PTCSC3 is a biomarker for the treatment and prognosis of gastric cancer. Cancer Biother Radiopharm 2020;35:77-81.

79. Zhang J, Guo S, Piao HY, Wang Y, Wu Y, Meng XY, et al. ALKBH5 promotes invasion and metastasis of gastric cancer by decreasing methylation of the IncRNA NEAT1. J Physiol Biochem 2019;75:379-89.

80. Huang Y, Zhang J, Hou L, Wang G, Liu H, Zhang R, et al. LncRNA AK023391 promotes tumorigenesis and invasion of gastric cancer through activation of the PI3K/Akt signaling pathway. J Exp Clin Cancer Res 2017;36:194.
81. Wang H, Wu M, Lu Y, He K, Cai X, Yu X, et al. LncRNA MIR4435-2HG targets desmoplakin and promotes growth and metastasis of gastric cancer by activating $W n t / \beta$-catenin signaling. Aging (Albany NY) 2019;11:6657-73.

82. Li D, Wang J, Zhang M, Hu X, She J, Qu X, et al. LncRNA MAGI2-AS3 is regulated by BRD4 and promotes gastric cancer progression via maintaining ZEB1 overexpression by sponging miR-141/200a. Mol Ther Nucleic Acids 2020;19:109-23.

83. Zhou L, Zhang Y, Jin J, Gu X. Correlation between IncRNA SNHG16 gene polymorphism and its interaction with environmental factors and susceptibility to colorectal cancer. Medicine (Baltimore) 2020;99:e23372.

84. Wang L, Cho KB, Li Y, Tao G, Xie Z, Guo B. Long noncoding RNA (IncRNA)-mediated competing endogenous RNA networks provide novel potential biomarkers and therapeutic targets for colorectal cancer. Int J Mol Sci 2019;20:5758.

85. Han D, Gao X, Wang M, Qiao Y, Xu Y, Yang J, et al. Long noncoding RNA H19 indicates a poor prognosis of colorectal cancer and promotes tumor growth by recruiting and binding to elF4A3. Oncotarget 2016;7:22159-73.

86. Wang W, Xie Y, Chen F, Liu X, Zhong LL, Wang HQ, et al. LncRNA MEG3 acts a biomarker and regulates cell functions by targeting ADAR1 in colorectal cancer. World J Gastroenterol 2019;25:3972-84.

87. El-Ashmawy NE, Hussien FZ, El-Feky OA, Hamouda SM, Al-Ashmawy GM. Serum LncRNA-ATB and FAM83H-AS1 as diagnostic/prognostic non-invasive biomarkers for breast cancer. Life Sci 2020;259:118193.

88. Xiao B, Zhang W, Chen L, Hang J, Wang L, Zhang R, et al. Analysis of the miRNA-mRNA-IncRNA network in human estrogen receptor-positive and estrogen receptor-negative breast cancer based on TCGA data. Gene 2018;658:28-35.

89. Shao X, Huang P, Shi L, Lei L, Cao W, Chen Z, et al. MicroRNA and LncRNA expression profiles in human estrogen receptor positive breast cancer. Clin Lab 2019. doi: 10.7754/Clin. Lab.2018.180340.

90. Zhang D, Du D, Yi S, Li X. LncRNA PCAT6: a potential biomarker for diagnosis and prognosis of bladder cancer. Ann Diagn Pathol 2020;49:151642.

91. Quan J, Pan X, Zhao L, Li Z, Dai K, Yan F, et al. LncRNA as a diagnostic and prognostic biomarker in bladder cancer: a systematic review and meta-analysis. Onco Targets Ther 2018;11:6415-24.

92. Liu P, Sun QQ, Liu TX, Lu K, Zhang N, Zhu Y, et al. Serum InCRNA-UFC1 as a potential biomarker for diagnosis and prognosis of pancreatic cancer. Int $\mathrm{J}$ Clin Exp Pathol 2019;12:4125-9.

93. Naizhaer G, Kuerban A, Meilipa, Kuerban R, Zhou P. Upregulation of IncRNA FALEC indicates prognosis and diagnosis values in cervical cancer. Pathol Res Pract 2019;215:152495.

94. Li N, Zhan X. Identification of clinical trait-related IncRNA and mRNA biomarkers with weighted gene co-expression network analysis as useful tool for personalized medicine in ovarian cancer. EPMA J 2019;10:273-90. 
95. Chen X, Zhou Y, Liu S, Zhang D, Yang X, Zhou Q, et al. LncRNA TP73-AS1 predicts poor prognosis and functions as oncogenic IncRNA in osteosarcoma [published online ahead of print September 14, 2018]. J Cell Biochem. doi: 10.1002/ jcb. 27556.

96. Huang DN, Liu HW, Li ZD. Expression of IncRNA-ATB in laryngeal carcinoma and its relationship with prognosis. Eur Rev Med Pharmacol Sci 2020;24:11148-53.

97. Tan SK, Pastori C, Penas C, Komotar RJ, Ivan ME, Wahlestedt $C$, et al. Serum long noncoding RNA HOTAIR as a novel diagnostic and prognostic biomarker in glioblastoma multiforme. Mol Cancer 2018;17:74.

98. Redis RS, Sieuwerts AM, Look MP, Tudoran O, Ivan C, Spizzo $\mathrm{R}$, et al. CCAT2, a novel long non-coding RNA in breast cancer: expression study and clinical correlations. Oncotarget 2013;4: 1748-62.

99. Shen X, Xie B, Ma Z, Yu W, Wang W, Xu D, et al. Identification of novel long non-coding RNAs in triple-negative breast cancer. Oncotarget 2015;6:21730-9.

100. Xue X, Yang YA, Zhang A, Fong KW, Kim J, Song B, et al. LncRNA HOTAIR enhances ER signaling and confers tamoxifen resistance in breast cancer. Oncogene 2016;35:2746-55.

101. Fang Z, Wang Y, Wang Z, Xu M, Ren S, Yang D, et al. ERINA is an estrogen-responsive LncRNA that drives breast cancer through the E2F1/RB1 pathway. Cancer Res 2020;80:4399413.

102. Jin X, Ge LP, Li DQ, Shao ZM, Di GH, Xu XE, et al. LncRNA TROJAN promotes proliferation and resistance to CDK4/6 inhibitor via CDK2 transcriptional activation in ER+ breast cancer. Mol Cancer 2020;19:87.

103. Mitobe $Y$, Ikeda K, Suzuki T, Takagi K, Kawabata H, Horie-Inoue $\mathrm{K}$, et al. ESR1-stabilizing long noncoding RNA TMPO-AS1 promotes hormone-refractory breast cancer progression. Mol Cell Biol 2019;39:e00261-19.

104. Zhang Y, Li Z, Chen M, Chen H, Zhong Q, Liang L, et al. IncRNA TCL6 correlates with immune cell infiltration and indicates worse survival in breast cancer. Breast Cancer 2020;27:573-85.

105. Li Y, Jiang B, Wu X, Huang Q, Chen W, Zhu H, et al. Long non-coding RNA MIAT is estrogen-responsive and promotes estrogen-induced proliferation in ER-positive breast cancer cells. Biochem Biophys Res Commun 2018;503:45-50.

106. Li M, Chai HF, Peng F, Meng YT, Zhang LZ, Zhang L, et al. Estrogen receptor $\beta$ upregulated by IncRNA-H19 to promote cancer stem-like properties in papillary thyroid carcinoma. Cell Death Dis 2018;9:1120.

107. Yu W, Ding J, He M, Chen Y, Wang R, Han Z, et al. Estrogen receptor $\beta$ promotes the vasculogenic mimicry (VM) and cell invasion via altering the IncRNA-MALAT1/miR-145-5p/NEDD9 signals in lung cancer. Oncogene 2019;38:1225-38.

108. Ding J, Yeh CR, Sun Y, Lin C, Chou J, Ou Z, et al. Estrogen receptor $\beta$ promotes renal cell carcinoma progression via regulating LncRNA HOTAIR-miR-138/200c/204/217 associated CeRNA network. Oncogene 2018;37:5037-53.

109. Liu S, Lai W, Shi Y, Liu N, Ouyang L, Zhang Z, et al. Annotation and cluster analysis of long noncoding RNA linked to male sex and estrogen in cancers. NPJ Precis Oncol 2020;4:5.

110. Yang L, Lin C, Jin C, Yang JC, Tanasa B, Li W, et al. IncRNAdependent mechanisms of androgen-receptor-regulated gene activation programs. Nature 2013;500:598-602.

111. Zhang A, Zhao JC, Kim J, Fong KW, Yang YA, Chakravarti D, et al. LncRNA HOTAIR enhances the androgen-receptor-mediated transcriptional program and drives castration-resistant prostate cancer. Cell Rep 2015;13:209-21.

112. Takayama K, Horie-Inoue K, Katayama S, Suzuki T, Tsutsumi $\mathrm{S}$, Ikeda $\mathrm{K}$, et al. Androgen-responsive long noncoding RNA CTBP1-AS promotes prostate cancer. EMBO J 2013;32:166580.

113. Zhang Y, Pitchiaya S, Cieślik M, Niknafs YS, Tien JC, Hosono $Y$, et al. Analysis of the androgen receptor-regulated IncRNA landscape identifies a role for ARLNC1 in prostate cancer progression. Nat Genet 2018;50:814-24.

114. Lingadahalli S, Jadhao S, Sung YY, Chen M, Hu L, Chen X, et al. Novel IncRNA LINC00844 regulates prostate cancer cell migration and invasion through AR signaling. Mol Cancer Res 2018;16:1865-78.

115. Chen Z, Song X, Li Q, Xie L, Guo T, Su T, et al. Androgen receptor-activated enhancers simultaneously regulate oncogene TMPRSS2 and IncRNA PRCAT38 in prostate cancer. Cells 2019;8:864.

116. Zhang P, Lu Y, Kong Z, Zhang Y, Fu F, Su X, et al. Androgenresponsive IncRNA LINC00304 promotes cell cycle and proliferation via regulating CCNA1. Prostate 2019;79:994-1006.

117. Zhai W, Sun Y, Guo C, Hu G, Wang M, Zheng J, et al. LncRNASARCC suppresses renal cell carcinoma (RCC) progression via altering the androgen receptor(AR)/miRNA-143-3p signals. Cell Death Differ 2017;24:1502-17.

118. Bai JY, Jin B, Ma JB, Liu TJ, Yang C, Chong Y, et al. HOTAIR and androgen receptor synergistically increase GLI2 transcription to promote tumor angiogenesis and cancer stemness in renal cell carcinoma. Cancer Lett 2021;498:70-9.

119. Schmidt K, Carroll JS, Yee E, Thomas DD, Wert-Lamas L, Neier $\mathrm{SC}$, et al. The IncRNA SLNCR recruits the androgen receptor to EGR1-bound genes in melanoma and inhibits expression of tumor suppressor p21. Cell Rep 2019;27:2493-507.e4.

120. Cao Y, Zhang R, Luo X, Yang Y. LncRNA PART1 promotes lung squamous cell carcinoma progression via miR-185-5p/Six1 axis. Hum Exp Toxicol 2021;40:960-76.

121. Lou T, Ke K, Zhang L, Miao C, Liu Y. LncRNA PART1 facilitates the malignant progression of colorectal cancer via miR-150-5p/ LRG1 axis. J Cell Biochem 2020;121:4271-81. 